\title{
СВІТ КУКУТЕНЬ-ТРИПІЛЛЯ
}

\section{ВАРІАНТИ ЖИТЛОВИХ БУДІВЕЛЬ ТРИПІЛЬСЬКОЇ КУЛЬТУРИ ЗА ЕЛЕМЕНТАМИ ІНТЕР'СРУ ДРУГОГО ПОВЕРХУ}

У статті розглянуто варіанти житлових споруд трипільської культури за елелентали інтер'єру другого поверху будівлі. Інтер'єр трипільських будівель досить стандартизований. Варіанти виділено за незначнили змінами в інтер'єрі житлового прилішення будівлі. Загалом запропоновано п'ятнадиять варіантів житлових споруд. Варіанти розподілено у хронологічній послідовності залежно від їхньої полви. За виділенили варіантали висловлено припущення щодо причини змін, які відбулися за час розвитку трипільської культури.

Ключові слова: трипільська культура, варіанти житлових будівель, площадка, інтер'ер.

Проведений аналіз будівель трипільської культури, за результатами багаторічних археологічних розкопок, говорить про те, що за облаштуванням внутрішнього житлово-господарського простору вони стандартизовані. У будівлі обов'язковим елементом інтер'єру виступає піч, яка завжди знаходиться праворуч від входу в житлове приміщення. Інші елементи інтер'єру, такі як вівтар, подіум, прибудови тощо є ситуативними. У статті запропоновано за наявністю чи відсутністю того чи іншого елементу інтер'єру у споруді виділити варіанти трипільських житлових будівель. Поява того чи іншого варіанту розглянута у хронологічній послідовності. Варіанти виділено лише за інтер'єром другого поверху будівель.

Раніше за елементами інтер'єру другого поверху було розглянуто лише будівлі томашівської локальної групи етапу CI розвитку культури. За результатами досліджень для щієї групи було виділено чотири варіанти споруд (Chernovol 2012). За елементами інтер'єру першого поверху для всіеї культури було запропо- новано дві групи будівель - A і В. До групи А були віднесені будівлі, в яких інтер'ер першого поверху відсутній, до групи В - будівлі 3 наявними елементами інтер'єру на першому поверсі (Черновол 2015). За окресленими о3наками інші локально-хронологічні утворення розглядалися лише опосередковано (Черновол, Сохацький 2010; Черновол 2013; 2016). У даній публікації залучено результати досліджень інтер'єру житлових будівель трипільської культури всіх локально-хронологічних груп та періодів розвитку культури, від другої половини XX ст. і до теперішнього часу.

Перший варіант (рисунок, таблиця) - це будівлі, що відносяться до раннього Трипілля, в яких у приміщенні вздовж довгого правого боку знаходилася вимостка. Вказана вимостка інтерпретувалася як місце розташування печі або відкритого вогнища. 3 протилежної сторони, навпроти неї, в деяких випадках виявлено ще одну подібну вимостку, яка морфологічно не відрізнялася від попередньої, проте, мала значно менші розміри. Беручи за основу розташування об'єктів інтер'єру в будівлях на інших етапах розвитку трипільської культури, перша вимостка, яка розташовувалася праворуч від входу, являла собою піч, друга, відповідно, робоче місце, що розміщувалося навпроти печі. За вказаними критеріями до цього варіанту слід віднести площадки поселення Бернашівка I, № 8, 10, 11, 13, 15 (Черновол 2016), площадку 4 поселення Ленківці (Черниш 1959), площадку 3 поселення Сабатинівка II (Макаревич 1960). Відмінність від будівель наступних етапів розвитку культури полягала лише в тому, що вірогідна піч розташовувалася за два метри від торцевої стіни, отже, була віддалена від місця входу в житлове приміщення. 
Другий варіант (рисунок, таблиця) - це будівлі раннього Трипілля, в яких виявлено ще по одній вимостці у правому стосовно входу дальньому куті будівлі. До таких належать площадка 4 поселення Ленківці (Черниш 1959), площадка 3 Сабатинівка II (Макаревич 1960). За запропонованою схемою, об'єкт, виявлений у торці будівлі, слід вважати вівтарем. Таким чином, ми отримаємо ще один варіант будівлі, але вже з елементами інтер'еру сакрального призначення. Об’єкт на площадці 3 поселення Сабатинівка II M. Л. Макаревич інтерпретував, як стільчик-троник, однак, дані польової документації не підкріплюють це твердження (Макаревич 1948). Проте, імовірно, можна виділити ще один варіант споруд з вимостками в торці будівлі, які могли мати сакральне призначення.

Однак, наявність вівтарів у житлах періоду раннього Трипілля залишається під запитанням.

Третій варіант (рисунок, таблиця) - належать будівлі з вимосткою по центру приміщення. Зокрема, до таких належать площадка 2 поселення раннього Трипілля Тимкове (Бурдо, Відейко 1985, с. 78). Проте, в польовій документації дані про цей об’ект відсутні (Бурдо 1981), можливо, автор переосмислив результати польових досліджень. Кам'яну вимостку із річкового плаского каміння в центрі площадки 2 поселення Белелуя I. Т. Кочкін вважав за вогнище (Кочкин 1987). Подібне облаштування вогнища виявлено на площадщі 11 поселення Бернашівка I, різниця лише в місці його розташування (Черновол 2016). Отже, третій варіант представлений лише однією будівлею з поселення Тимкове, можливо, ще спорудою 3 поселення Белелуя етапу BI-II.

Розподіл жител раннього періоду культури на окремі приміщення вкрай важко визначити, оскільки відсутні основні ознаки поділу поріг, залишки перегородки, піч, яка розташовувалася в глибині приміщення, а не відразу біля входу. Хоча, в двох випадках і було виявлено конструкцію, морфологічно подібну до порогу, це площадки 13, 15 поселення Бернашівка I (Черновол 2016), їі функціональне призначення доведено не було. Якщо прийняти џю конструкцію за поріг, то в одному випадку вхід до житлової частини знаходився з короткої сторони будівлі, через вхідне приміщення. Це площадка 15 , яка відповідае класичним уявленням про облаштування житлового простору. В іншому випадку, судячи з розташування порогу, вхід до споруди знаходився з краю довгої стіни будівлі, що не має аналогів серед інших споруд трипільської культури.

Отже, наразі ми маємо перших три варіанти житлових споруд, які відносяться виключно до етапу А розвитку трипільської культури.

Четвертий варіант (рисунок, таблиця) будівлі, в яких у житловому приміщені знахо-
Варіанти площадок трипільської культури, двоповерхові будівлі першого типу

\begin{tabular}{|c|c|c|c|c|c|}
\hline \multirow{2}{*}{ Варіант } & \multicolumn{5}{|c|}{ Період } \\
\cline { 2 - 6 } & A & BI & BII & CI & CII \\
\hline 15 & - & - & - & $+(1)$ & - \\
14 & - & - & - & + & - \\
13 & - & - & - & + & - \\
12 & - & - & - & $+(1)$ & - \\
11 & - & - & + & - & - \\
10 & - & - & $+(1)$ & - & - \\
9 & - & - & + & + & - \\
8 & - & + & - & - & $+?$ \\
7 & - & + & - & - & - \\
6 & - & $+(1)$ & + & $+?$ & $+(1)$ \\
5 & - & $+(1)$ & - & - & - \\
4 & - & + & + & + & $+(1)$ \\
3 & $+(1)^{*}$ & - & $+(1) ?$ & - & - \\
2 & + & - & - & - & - \\
1 & + & - & - & - & - \\
\hline
\end{tabular}

дилася лише піч та робоче місце навпроти неї. Відмінність від першого варіанту, виділеного в ранньому Трипіллі, полягае лише в місці розташування печі та робочого місця навпроти. Піч у четвертому варіанті розташовано відразу праворуч від входу в житлове приміщення. Вперше такі будівлі виявлено на етапі ВI розвитку культури, поселення Глибочок Тернопільської області, площадки 1, 2 (Сохацький 1992; Черновол, Сохацький 2010). Будівлі цього варіанту продовжують існувати до останньої фрази існування культури.

П’ятий варіант (рисунок, таблиця) - будівля, яка імовірно мала дві печі, що були розташовані праворуч від входу - одна відразу біля входу, інша — в глибині приміщення Ця будівля відноситься до етапу ВI поселення Глибочок Тернопільської обл., площадка 3 (Сохацький 1995; Черновол, Сохацький 2010). Потреба у додатковій печі могла бути викликана великою площею житлового приміщення $-166 \mathrm{~m}^{2}$. Одніеї печі, можливо, було недостатньо для обігріву даного приміщення. Та якщо навіть другий об'єкт не вважати піччю, то в інших трипільських будівлях саме в цьому місці жодних елементів інтер'єру виявлено не було. Цей варіант представлений лише однією площадкою.

Шостий варіант (рисунок, таблиця) будівля, у якої крім печі, у торці знаходилися рештки імовірно прямокутної конструкції. За запропонованими реконструкціями об'єкти в торці будівлі вважаються вівтарями. Вперше подібну площадку було розкопано на поселенні Поливанів Яр III, етапу ВI (Пассек 1961, c. 106-116; Попова 2003, с. 16). У жодній споруді етапу ВI та раннього Трипілля подібного об’екта виявлено не було. Будівлі цього варіан- 


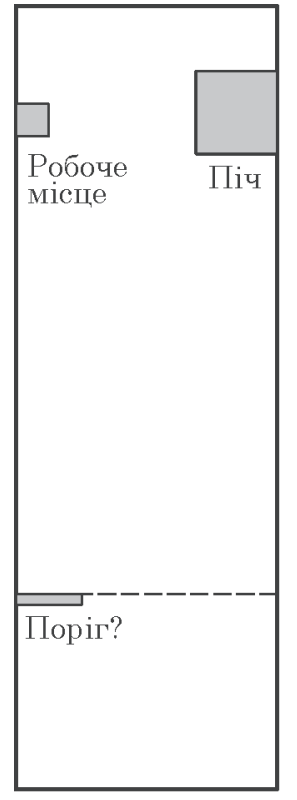

Варіант 1

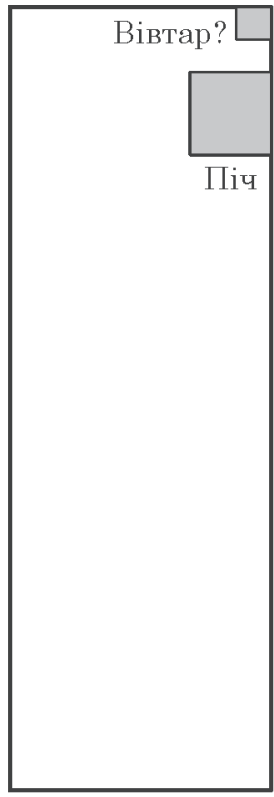

Bаріант 2

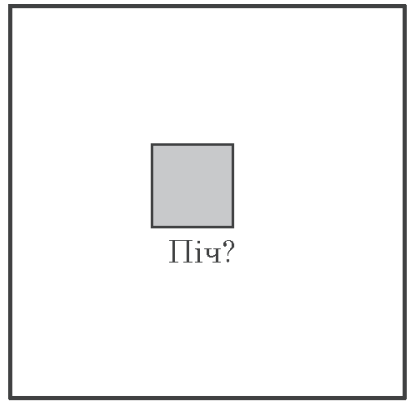

Варіант 3

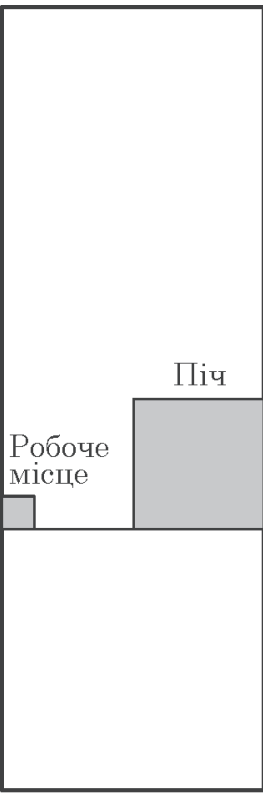

Bapiант 4

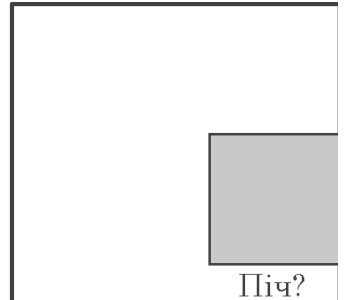

Піч?

Пiч

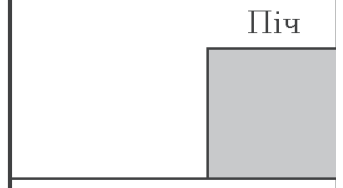

Варіант 5

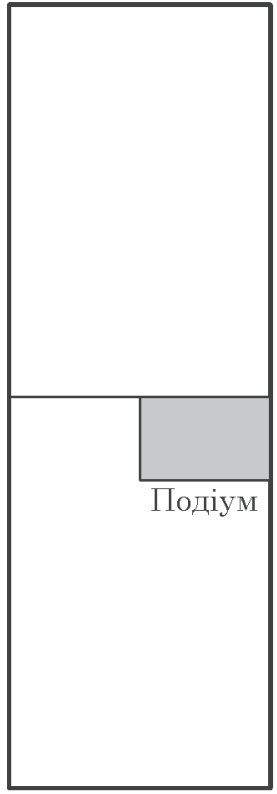

Bapiaнт 12

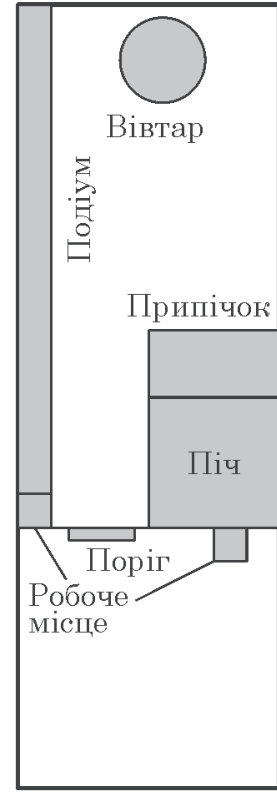

Варіант 13

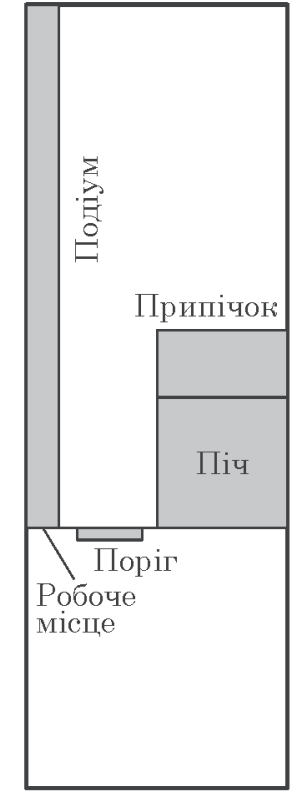

Bapiaнт $13(1)$

Варіанти трипільських будівель за розташуванням елементів інтер'єру другого поверху

ту продовжують існувати до останньої фрази розвитку культури.

Сьолий варіант (рисунок, таблиця) - будівлі, в яких на місці розташування вівтаря були встановлені стаціонарні посудини. Такі площадки виявлено лише на поселенні Ожеве-острів етапу BI (Chernovol 2014) Подібні об'єкти не виявлено в жодній споруді і раніших, і в наступ- 


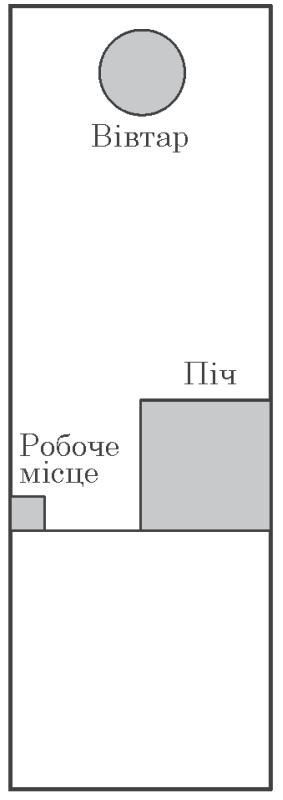

Варіант 6

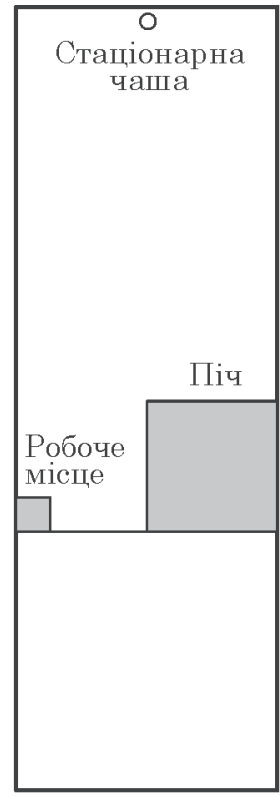

Варіант 7

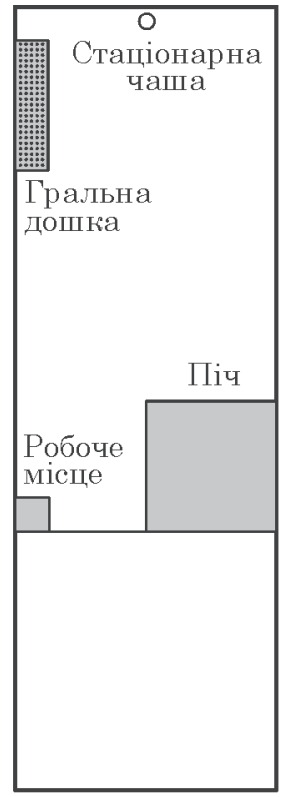

Варіант 8

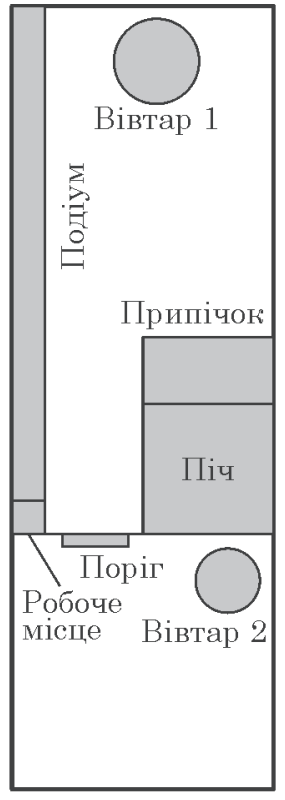

Варіант 9 (1)

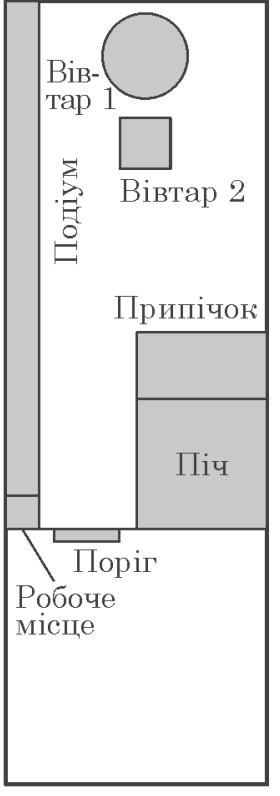

Варіант 9 (2)

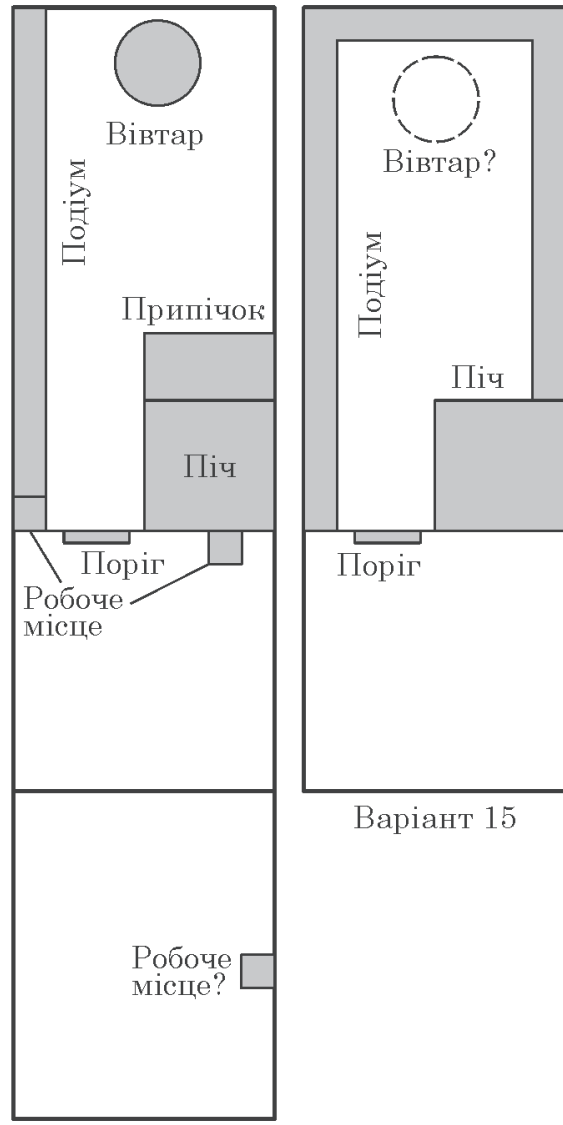

Варіант 14

ні періоди розвитку культури. Тому такі будівлі запропоновано виділити в окремий варіант.

Восьлий варіант (рисунок, таблиця) будівлі, в яких окрім інших об’ектів інтер'еру, у торці будівлі були встановлені стаціонарні гральні дошки. Дошки були розташовані у житловому приміщені вздовж довгого лівого боку будівлі. Вперше такі площадки з'явилися на етапі BI поселення Ожеве-острів, площадки 1, 3 (Chernovol 2014). В інших локальнохронологічних утвореннях виявлено подібні стаціонарні гральні дошки, проте не вказано місце їхнього розташування у споруді. А саме, площадка 17 поселення Коломийщина I етапу BII-CI (приватний архів М. Л. Макаревича). На етапі CII площадка 1 поселення Волошкове 6 виявлено стаціонарну гральну дошку в перевідкладеному стані, місце її реального розташування у будівлі невідоме (Черновол 2017). Отже, можна припустити, що даний варіант будівлі існував і на інших етапах розвитку культури.

У спорудах поселення Незвисько етапу ВI було виявлено елементи інтер'єру, в основу яких було закладене каміння (Черныш 1962). Проте, невідомо до якого поверху будівлі ці об'єкти належали. Це в цілому не дозволяе виділити їх в окремий варіант будівель, хоча відмінність в облаштуванні об'єктів інтер'еру від інших споруд цього періоду очевидна. Подібний конструктивний прийом також зафріксовано в будівлях пізнішого часу, проте на інших поселеннях етапу ВI у жодному випадку такого не було виявлено. Вірогідно, цей прийом був характерний тільки для жител цього поселення, чи для певної групи поселень, однак для останнього припущення недостатньо даних.

Дев'ятий варіант (рисунок, таблиця) будівлі, в яких виявлено два вівтаря, один у торці будівлі, інший у вхідному приміщенні. Найраніше такі будівлі, на думку О. В. Цвек, з'явилися на етапі BI-II поселення Шкарівка, площадка 5 (Цвек 1976). Проте, вона вважа- 
ла, що в цій споруді не два, а більше вівтарів (Цвек 1993). Однак, на мою думку, виявлені на цій площадці конструкщії можна розглядати як об'єкти господарського призначення і лише прямокутну конструкцію в торці споруди можна вважати вівтарем. Окрім того, в звіті автор розкопок впевнено вказуе лише на два підвищення квадратної форми (Цвек 1972). Одне з підвищень, яке знаходилося вздовж довгої сторони будівлі, було зруйноване та не підлягало реконструкції. Опис інших елементів інтер'єру, які з'являються надалі в реконструкціях, у звіті відсутні (Цвек 1972). Достовірно будівлі 3 двома вівтарями відомі з поселення Володимирівка етапу BII (Пассек 1949) та площадка 6 поселення Тальянки етапу CI (Круц, Рыжов, Шумова 1983). Один з вівтарів знаходився в торці будівлі навпроти входу у житлове приміщення, тобто в місці його класичного розташування, другий вівтар знаходився 3 правого боку вхідного приміщення.

Проте, у дев’ятого варіанту є підваріант: це коли обидва вівтарі розташовано у житловому приміщенні в торці будівлі, площадка 14 поселення Тальянки етапу CI (Круц, Рыжов, Клочко 1986)

Десятий варіант (рисунок, таблиця) будівля з прибудовою у вигляді накриття, що знаходилося перед входом. Вперше такі площадки виявлено на етапі BII поселення Піщана (площадка 2) небелівської локальної групи. Зокрема, у неї перед вхідним приміщенням на відстані 0,4 м грунт був підмащений тонким шаром глини на площі $3 \times 4$ м. Зверху цієї ділянки шар підмазки перекривали спорадичні шари глини з рослинними домішками. Їх було інтерпретовано як залишки прибудови чи накриття, що знаходилося перед входом до будівлі (Черновол, Рижов 2005;Черновол 2012). До цього ж варіанту можна віднести площадку 2 поселення Коломийщина II етапу ВII. В останній будівлі житлове приміщення мало розміри 1246 м, вхідне приміщення - $6 \times 6$ м, прибудова $-9 \times 6$ м (Пассек 1949 , с. 58$)$.

Одинадиятий варіант (рисунок, таблиця) - будівля, в якої було відсутне вхідне приміщення. Вірогідно вхід до споруди, зокрема на другий поверх, на думку С. М. Рижова, знаходився 3 торця будівлі, через округлий лаз, облаштований у міжповерховому перекритті (Рижов, Шумова, Черновол 2005). До цього варіанту належить площадка 2 поселення Колодисте II етапу BII небелівської локальної групи. Відсутність вхідного приміщення могла бути обумовлена високою щільністю забудови на даній ділянці цього поселення. Тому будівничі, імовірно, відмовилися від будівництва сіней та зробили вхід до житлової частини не 3 двору, а з рівня першого поверху будівлі, чим зменшили їі площу, при цьому зберігши загальну житлову площу будівлі, придатну для проживання у ній їі мешканців.
Дванадиятий варіант (рисунок, таблиця) - будівля, в якої вздовж перегородки, яка розділяе споруду на приміщення, знаходився подіум, інших елементів інтер'еру у ній виявлено не було. Подібне розміщення подіуму в інших будівлях трипільської культури невідоме. Цю площадку було виявлено на поселенні Ріпниця 1 етапу BII-CI (Рижов 2002). Можливо, таке розміщення подіуму є виключенням, раціонального пояснення на сьогодні цьому немає. С. М. Рижов вважав цю будівлю не житловою, а спорудою господарського призначення. Проте, на який вид господарської діяльності вона була спрямована дослідником не уточнювалось, що ставить під сумнів його припущення.

Тринадиятий варіант (рисунок, таблиця) будівлі томашівської локально-хронологічної групи етапу CI. Особливістю цих будівель є поява у житловому приміщенні подіуму вздовж довгого боку, ліворуч від входу, за іншими елементами інтер'єру вони подібні до шостого варіанту (Черновол 2008; Chernovol 2012). Споруди томашівської групи мають підваріанти, зокрема для більшості будівель обов'язковими є вівтарі. Проте, на поселенні Зелена Діброва, що належить до цієї локальної групи, було розкопано дві будівлі без вівтарів, що наближає їх до четвертого варіанту, та відрізняе від інших у томашівській групі (Овчинников, Черновол 2001; Овчинников 2014). Отже, виникає питання - можливо ця відмінність притаманна лише цьому поселенню та є окремим варіантом будівлі? Оскільки відповіді поки що немає, будівлі поселення Зелена Діброва запропоновано вважати підваріантом тринадцятого варіанту площадок.

Чотирнадиятий варіант (рисунок, таблиця) - будівлі 3 прибудовою, де прибудова виступала частиною платформи. Подібні споруди з'являються на етапі CI у томашівській локальній групі. Для прикладу взято площадку 40 поселення Тальянки (Круц и др. 2008). Прибудова була зроблена до вхідної частини у будівлю, їі розміри становили $5 \times 5,4$ м. На другому поверсі у прибудові був виявлений об'єкт, що за своїми зовнішніми ознаками схожий на черінь печі в житловому приміщенні. Він був виготовлений з глини без рослинних домішок, мав розміри $1 \times 1 \mathrm{M}$, завтовшки $0,25 \mathrm{M}$. Розташований з того самого боку, що і піч у житловому приміщені, вздовж довгого боку будівлі. Подібна за конструкцією і площадка 47 поселення Тальянки (Круц и др. 2013). Розміри прибудови становили $4 \times 4 \mathrm{M}$, таких самих розмірів було вхідне приміщення. Жодного об’єкта у прибудові цієї площадки виявлено не було.

На площадщі № 40 шар обмазки прибудови від шару обмазки вхідного приміщення відрізнявся лише завалом стін у вхідному приміщенні. Жодних слідів, які б підтверджували, що прибудова була окремим приміщенням, ви- 
явлено не було. Фактично прибудову на площадщі 40 можна було б вважати продовженням вхідного приміщення, яке тоді мало би довжину 12 м, довжина житлового приміщення при цьму становила 8 м.

Окрім того, на думку авторів розкопок, вказана прибудова мала господарське призначення. У разі якщо це прибудова, і вона є окремим приміщенням, то чому слід вважати їі господарською за призначенням, а не житловою? Адже жодних ознак, які вказували б на господарське призначення ціеї прибудови, виявлено не було. Навпаки, виявлено конструкцію, аналогічну печі, що може вказувати на житлове призначення приміщення. Проте, надалі виникає питання, де був вхід до споруди: з боку сіней чи 3 торця будівлі. Якщо піч знаходиться завжди праворуч від входу, то вхід був з торця будівлі. Тоді прибудову слід вважати прохідною кімнатою до інших приміщень, яке було спочатку сіньми, та вело далі, до наступного житлового приміщення 3 усіма його атрибутами: подіумом, вівтарем, піччю тощо. Якщо вхід був збоку, вздовж довгої сторони будівлі, то піч у прибудові повинна була знаходитися праворуч від входу в приміщення. Ці питання потребують подальших досліджень. Проте, ми маємо варіант споруди з великим вхідним приміщенням, що перевищуе за розмірами житлове приміщення. Иого можна інтерпретувати як окрему кімнату, яке $є$ прибудовою до основної споруди.

До ціеї групи жител можна віднести будівлі 33, 41, які виявлені на поселенні Тальянки (Круц и др. 2005, 2008). У цих спорудах перед вхідним приміщенням було виявлено завал конструкцій, який за складом глини морфологічно був схожий до печей. Поруч 3 ними знаходилися фррагменти платформи. Вони були проінтерпретовані як вимостки перед площадками, хоча мали яскраві відмінності від останніх. Зокрема, було простежено, що вони утворилися в результаті падіння, а не намащені на Iрунт. Окрім того, товщина цих фррагментів становила близько 10 см, що робить їх подібними до фррагментів череня печі.

Не виключено, що це були залишки прибудови, подібної до конструкції на площадщі № 40 поселення Тальянки. Однак, температурні режими були недостатні для випалу платформи, тому збереглася лише конструкція, яка знаходилась у приміщенні. Характерно, що у прибудові площадки 40 сліди горіння та, відповідно, температурні режими були нижчі, ніж у сінях та житловому приміщенні.

До споруд, які мали прибудови, на думку авторів розкопок, відносилися будівля 2-4 поселення Косенівка етапу CII (Бузян, Якубенко 1990) та споруда 3 поселення Глибочок етапу ВI (Сохацький 1992). Однак, ці твердження нічим не аргументовані, окрім розмірів самих площадок. Автори припускали, що площадки, довжина яких становить близько 30 м, мусили мати прибудову.

П’ятнадиятий варіант (рисунок, таблиця) - будівля томашівської групи, у якій подіум огинав по периметру майже всю площу житлового приміщення, крім входу та місця розташування печі. Це комплекс «М» 3 поселення Майданецьке (Шмаглий, Видейко 1985). На кресленнях вівтар у цій будівлі відсутній (Шмаглий, Видейко 1985), що є нетиповим для площадок цієї групи, хоча в опублікованій реконструкції цієї будівлі він є (Відейко 2005; Відейко, Терпиловський, Петрашенко 2005). Втім, вівтар міг бути настільки зруйнованим, що не підлягав ідентифікації. Ця будівля виділена в окремий варіант, оскільки автор їі публікацій наполягав, що це залишки храму (Відейко, Терпиловський, Петрашенко 2005). Отже, особливості їі інтер'єру можуть вказувати на винятковість будівлі.

Раніше, розглядаючи варіанти будівель томашівської групи, було привернуто увагу до споруд без інтер'єру та зроблено спробу виділити ї в окремий варіант (Chernovol 2012). Для будівель томашівської групи це виглядає як виключення та потребуе пояснень. Оскільки площадки від цих споруд утворювалися під дією високих температурних режимів, то залишки від глинобитних конструкцій інтер'єру мусили б зберегтися. Таких площадок у томашівській групі не багато, втім вони є, зокрема це площадка поселення Чичиркозівка (Круц и др. 1984) та площадка поселення Мошурів Круц и др. 1981). В інших локально-хронологічних утвореннях також є площадки, де інтер'єру не виявлено, однак, це скоріше пов'язано зі слабкою дією вогню, ступенем руйнації площадки в результаті сільськогосподарських робіт. Можливо, дійсно він там був відсутній, можливо вплив людського фрактора, коли пересічному досліднику з вище означених причин не вдалося виявити об'єкт.

Отже, призначення цих будівель та їх виділення в окрему групу стоїть під запитанням. Оскільки, на сьогодні неможливо виявити різницю між площадками, де елементів інтер'єру з глини в будівлі взагалі не було та площадками, де він не зберігся.

Висновки. Загалом, на сьогодні за відмінністю в елементах інтер'єру запропоновано п'ятнадцять варіантів споруд трипільської культури. Однак, перші три варіанти зустрічаються виключно на ранньому етапі їі розвитку. Варіанти чотири та шість з'являються на етапі BI та продовжують існувати до етапу CII. Інші запропоновані варіанти мають незначні відхилення, які притаманні тому чи іншому етапу розвитку культури, чи окремо взятому поселенню. Організація та розміщення у будівлях елементів інтер'єру практично незмінна 3 етапу BI розвитку культури. Основна відмінність полягає лише у наявності чи відсутності 
вівтарів на площадках, проте, не всі локальні групи досліджені настільки, щоб дати остаточну відповідь на це питання.

Висока ступінь стандартизації трипільських будівель, ймовірно, була обумовлена тим, що будівництво споруд було колективним видом трудової діяльності. Не слід виключати й існування ряду табу, що не дозволяли відхилятися від прийнятих норм і правил. Певні індивідуальні елементи, ймовірно, могли з'явитися у випадку сімейного або індивідуального будівництва, в процесі фрункціонування будівлі чи 3 якихось суто раціональних причин. Наприклад, на глиняних моделях жител відкритого типу зображені практично всі деталі інтер'єру, окрім вимосток. Цей об’єкт міг знаходитися у будь-якій частині споруди, як це було імовірно зручно їі мешканцям.

Найбільша варіативність споруд простежуеться на етапі ВI. Виділені варіанти площадок не повторюються на інших поселеннях цього етапу розвитку культури. 3 десяти площадок, на яких виявлено елементи інтер'єру, виділено п'ять варіантів споруд трипільської культури. Площадки четвертого та п'ятого варіанту виявлено лише на поселені Глибочок, шостого варіанту — тільки на поселені Поливанів Яр III, сьомого та восьмого варіанту тільки на поселені Ожеве-острів. У наступні періоди розвитку культури повторів п'ятого, сьомого, восьмого варіантів не виявлено. Проте, в господарських ямах та в культурному шарі поселень інших етапів розвитку культури зустрічаються фррагменти гральних дощок, що вказуе на імовірність наявності на поселеннях будівель, віднесених до восьмого варіанту. Загалом, важко говорити про певний період чи локально-хронологічне утворення, де розкопано 1-3 площадки, оскільки це не надає повної уяви про реальний стан речей та не дає простежити співвідношення чи наявність тих чи інших варіантів площадок. У володимирськотомашівській лінії розвитку культури, де розкопано найбільше площадок, простежується найбільша варіабельність споруд. Проте, не відомо, чи є подібні варіанти у синхронних локально-хронологічних утвореннях.

Докорінна відмінність в облаштуванні житлового простору простежуеться тільки між будівлями раннього етапу розвитку культури та всіма наступними, починаючи з етапу BI. Зокрема, це полягає в розташуванні вогнища в оселі, яке на ранньому етапі знаходилося в глибині житлового приміщення, а не відразу біля входу. Можливо, це явище було продиктоване більш ранніми традиціями, коли відбувся перехід від багатосімейного колективу до будинку з нуклеарною сім'єю. Відомо, що у багатосімейних будинках вогнища знаходились по центральній осі споруди (Морган 1934, c. 43). 3 переходом до нуклеарної сім'ї вогнище змістили 3 центральної осі будівлі під стіну, тим самим збільшили простір приміщення для життедіяльності ї мешканців. Зокрема, так виглядає площадка раннього Трипілля 3 поселення Тимкове (Бурдо, Відейко 1985). Вона мала квадратну фрорму $6 \times 6$ м, а не прямокутну, яка є традиційною для трипільського часу. Окрім того, за реконструкціею авторів, на ній у центрі приміщення знаходилося підвищення, яке могло бути вогнищем або піччю. За поданими вище ознаками, таким чином облаштовувалися будівлі більш раннього часу. Можливо, ця споруда $є$ пережитком чи відголоском більш ранніх часів розвитку людства.

Не виключено, що могли бути й інші причини, 3 яких піч у різні періоди існування культури змінювала своє місце розташування, зокрема, пов'язані з облаштуванням витяжки для диму. Можливо, в ранньому трипіллі за витяжку слугувало вікно в торці будівлі, тому вогнище було максимально наближене до нього. На етапі ВI відбулася зміна традицій, яка збереглася до кінця існування культури. Піч була перенесена до входу, певною мірою це було продиктовано раціоналізмом. Подібне розташування печі стало перешкодою для проникнення холодного повітря в житлове приміщення. Тому, імовірно, було переоблаштовано і витяжку для диму. Скоріше за все, отвір було зроблено в даху чи десь поруч з піччю. Не виключено, що саме в цей період відбулася заміна відкритого вогнища в ранньому Трипіллі на купольну піч в наступні періоди розвитку культури, де устя печі було спрямоване до входу. Оскільки, для цілеспрямованого напрямку тепла в певну точку необхідні склепіння та устя.

Зміна у розташуванні печі могла бути пов'язана зі зміною клімату, яка відбулася в цей період, про що зауважуе ряд дослідників (зокрема: Anthony 2007; Bicbaev 2010; Дяченко 2010; Harper et al. 2019). За даними споропилкового аналізу, взятого з поселення Ожеве-острів, було встановлено, що в час його існування клімат був спекотний влітку та відповідно холодний взимку (Герасименко, Юрченко, Черновол 2018). Отже, причина зміни розташування печі була пов'язана з необхідністю раціонального використання теплових режимів у житловому приміщенні.

Загалом, ряд факторів, зокрема, зміна клімату чи можлива поява іноетнічного населення в трипільському середовищі, могли вплинути на зміну інтер'єру в спорудах на етапі ВI розвитку трипільської культури та започаткувати нові традиції в організації житлового простору.

\section{ЛIТЕРАТУРА}

Бузян, Г. Н., Якубенко, Е. А. 1990. Характерные черты домостроительства Косеновской локальной группы. В: Збенович, В. Г. (ред.). Раннезелледельческие поселения-гиганты трипольской культуры на Украине. Тезисы докладов 1-го полевого селинара. Киев, с. 58-64. 
Бурдо, Н. Б. 1981. Отчет о работе Буго-Днестровского отряда Причернолорской экспедиции ОАМ АН УССР в 1981 г. НА IA НАН України, ф. 64, $1981 / 79$.

Бурдо, Н. Б., Відейко, М. Ю. 1985. Ранньотрипільське поселення Тимкове в Одеській області. $A p$ хеологія, 52, с. 78-85.

Відейко, М. Ю. 2005. Протоміста трипільської культури: 4200-2750 pр. до н. е. В: Зубар, В. М. (ред.). Археологія у Києво-Могилянській Акаделії. Київ, с. 53-69.

Відейко, М. Ю., Терпиловський, Р. В., Петрашенко, В. О. 2005. Давні поселення Украӥни. Київ.

Герасименко, Н. П., Юрченко, Т. І., Черновол, Д. К. 2018. Природна й антропогенна трансформація рослинності та Ірунтового покриву на трипільському поселенні Ожеве-острів (Середне Придністер'я). В: Рельефб і клімат: Матеріали II-ой міжнародноі конферениї. Чернівці, с. 39-41.

Дяченко, А. В. 2010. Эвстатические колебания Черного моря и динамика развития населения кукутень-трипольской общности. Stratum plus, 2, с. 37-48.

Кочкин, И. Т. 1987. Отчет о работе экспедиции Ивано-Франковского государственного педагогического института ил. Стеббаника по исследованию трипольского поселения Белелуя-6 (ур. "Бавки») в 1987 г. НА ІА НАН України, фр. 64, 1987/110.

Круц, В. А., Рыжов, С. Н., Збенович, В. Г., Шумова, В. А. 1981. Отчет о работе тальянковского отряда Трипольской экспедииии за 1981 г. НА ІА НАН України, фр. 64, 1981/11б.

Круц, В. А., Рыжов, С. Н., Шумова, В. А. 1983. Отчет о работе тальянковского отряда Трипольской экспедиции за 1983 г. НА IA НАН України, фp. $64,1983 / 3 \mathrm{a}$.

Круц, В. А., Рыжов, С. Н., Шумова, В. А., Салий, Н. Г. 1984. Отчет о работе тальянковского отряда Трипольской экспедиции за 1984 г. НА IA НАН України, фр. 64, 1984/38.

Круц, В. А., Рыжов, С. Н., Клочко, В. И. 1985. Отчет о работе тальянковского отряда Трипольской экспедииии за 1985 г. НА ІА НАН України, фр. 64, 1985/23e.

Круц, В. А., Корвин-Пиотровский, А. Г., Рыжов, С. Н., Бузян, Г. Н., Овчинников, Э. В., Черновол, Д. К., Чабанюк, В. В. 2005. Исследования поселенийгигантов трипольской культуры 2002-2004 г2. Киев: Корвин-Пресс.

Круц, В. А., Корвин-Пиотровский, А. Г., Менотти, Ф., Рыжов, С. Н., Черновол, Д. К., Чабанюк, В. В. 2008. Трипольское поселение-гигант Тальянки. Исследования 2008 г. Киев.

Круц, В. А., Корвин-Пиотровский, А. Г., Чабанюк, В. В., Шатило, Л. А. 2013. Трипольское поселение-гигант Тальянки. Исследования 2012 г. Киев.

Макаревич, М. Л. 1948. Отчет Средне-Бугской экспедищии на поселении Сабатиновка II. HA IA НАН України, фр. 64, 1948/34.

Макаревич, М. Л. 1960. Об идеологических представлениях у трипольских племен. Записки Одесского археологического общества, 1 (34), с. 290-301.

Морган, Л. 1934. Дола и долашняя жизнь алериканских туземиев. Ленинград: Институт народов северов ЦИК СССР.

Овчинников, Э. В., Черновол, Д. К. 2001. Раскопки трипольского поселения Зелена Диброва. Археологічні відкриття в Україні 1999-2000 рр., с. 177-179.

Овчинников, Е. В. 2014. Трипільська культура Канівського Подніпров'я (етапи BII-CI). Київ: Олег Філюк.
Пассек, Т. С. 1949. Периодизация трипольских поселений. Материалы и исследования по археологии СССР, 10. Москва; Ленинград: АН СССР.

Пассек, Т. С. 1961. Раннезелледельческие (трипольские) плелена Поднестровья. Материалы и исследования по археологии СССР, 84. Москва: АН CCCP.

Попова, Т. А. 2003. Многослойное поселение Поливанов Яр: $K$ эволюиии трипольской культуры в Среднел Поднестровье. Санкт-Петербург: МАЭ PAH.

Рижов, С. М., Шумова, В. О., Черновол, Д. К. 2005. Дослідження трипільського поселення Колодисте II у 2004 р. Археологічні дослідження в Украӥні 20032004 pp., c. $274-276$.

Сохацький, М. П. 1992. Звіт про роботу археологічної експедииї̈ Боршівського відділу Тернопільського краєзнавчого музею у 1992 році. НА IA НАН України, фр. 64, 1992/109.

Сохацький, М. П. 1995. Звіт про роботу археологічної експедицї Борщівського відділу Тернопільського краєзнавчого музею у 1992 році. НА IA НАН України, фр. 64, 1995/40.

Цвек, Е. В. 1972. Отчет о раскопках трипольского поселения у с. Шкаровка Белоцерковского р-на Киевской области в 1971-1972 г. НА ІА НАН України, фр. 64, 1971-72/6.

Цвек, Е. В. 1976. Домостроительство и планировка трипольских поселений (по материалам расскопок в с. Шкаровка). В: Березанская, С. С. Отрощенко, В. В., Телегин, Д. Я. (ред.). Энеолит и бронзовый век Украины Исследования и материаль. Киев: Наукова думка, с. 46-69.

Цвек, О. В. 1993. Релігійні уявлення населення Трипілля. Археологія, 3, с. 74-90.

Черныш, Е. К. 1962. Неолит и энеолит юга европейской части СССР. Материаль и исследования по археологии СССР, 102, с. 5-85.

Черновол, Д. К., Рижов, С. М. 2005. Звіт Пішанського загону Трипільської експедицї за 2005 рік в с. Пішана Тальнівського району Черкаської обласmi. НА IA НАН України, фр. 64, 2005/135.

Черновол, Д. К. 2008. Интерьер трипольского жилища по материалам поселения Тальянки. В: Корвин-Пиотровский, А., Менотти, Ф. (ред.). Трипольская культура в Украине. Поселение-гигант Тальянки. Киев, с. 168-191.

Черновол, Д. К., Сохацький, М. П. 2010. Інтер'ер жител заліщицької локальної групи за матеріалами поселення Глибочок Борщівського району Тернопільської області. Археологія $і$ давня історія $У_{\kappa}$ раїни, 2, с. 32-35.

Черновол, Д. К. 2012. Інтер'єр будівель небелівської локальної групи трипільської культури. Археологiл, 1, с. 62-71.

Черновол, Д. 2013. Постройки петренской локальной группы. Revista Archeologică, IX, 1, с. 72-87.

Черновол, Д. К. 2015. Варіанти житлових споруд за елементами інтер'єру. В: На східній межі Старої Європи. Матеріали міжнародної наукової конфберениї. Кіровоград, с. 53.

Черновол, Д. 2016. Поселение трипольской культуры Бернашевка I. Revista Archeologică, XII, 1-2, c. $61-80$.

Черновол, Д. К. 2017. Дослідження в с. Волошкове. В: Археологія Буковини: здобутки та перспективи. Тези доповідей наукового семінару. Чернівці: Технодрук, с. 84-85.

Шмаглий, Н. М., Видейко, М. Ю. 1985 Отчет о работе Майданеикого отряда Трипольской эк- 
спедиции в 1985 году. НА IA НАН України, фр. 64, 1985/23в.

Anthony, D. 2007. The horse, the wheel and language. How Bronze Age riders from the Eurasian steppes shaped the modern world. Princepton: Princeton University.

Bicbaev, V. 2010. The Copper Age cemetery in Giurgiulesti. In: Anthony, D. (ed.). The lost world of Old Europe. Princepton: Princeton University, p. 212-224.

Chernovol, D. 2012. Houses of the Tomashovskaya local group. In: Menotti, F., Korvin-Piotrovskiy, A. G. (eds.). The Tripolye culture giant-settlements in Ukraine: formation, development and decline. Oxford: Oxbow Books, p. 182-210.

Chernovol, D. 2014. The Tripolye BI Dwellings in the Middle Dniester Region. In: Cucuteni Culture within the European Neo-Eneolithic Context: International Colloquium Cucuteni - 130. Piatra-Neamt: Constantin Matasa, p. 108-109.

Harper, T. K., Diachenko, A., Rassamakin, Y. Y., Kennett, D. J. 2019. Ecological dimensions of population dynamics and subsistence in Neo-Eneolithic Eastern Europe. Journal of Anthropological Archaeology, 53 , p. $92-101$.

\section{REFERENCES}

Buzian, G. N., Iakubenko, E. A. 1990. Kharakternye cherty domostroitelstva Kosenovskoi lokalnoi gruppy. In: Zbenovich, V. G. (ed.). Rannezemledelcheskie poseleniia-giganty tripolskoi kultury na Ukraine. Tezisy dokladov 1-go polevogo seminara. Kiev, s. 58-64.

Burdo, N. B. 1981. Otchet o rabote Bugo-Dnestrovskogo otriada Prichernomorskoi ekspeditsii OAM AN USSR v $1981 \mathrm{~g}$. NA IA NAN Ukrainy, f. 64, 1981/79.

Burdo, N. B., Videiko, M. Yu. 1985. Rannotrypilske poselennia Tymkove v Odeskii oblasti. Arkheolohiia, 52, s. 78-85.

Videiko, M. Yu. 2005. Protomista trypilskoi kultury: 4200-2750 rr. do n. e. In: Zubar, V. M. (ed.). Arkheolohiia u Kyievo-Mohylianskii Akademii. Kyiv, s. 53-69.

Videiko, M. Yu., Terpylovskyi, R. V., Petrashenko, V. O. 2005. Dauni poselennia Ukrainy. Kyiv.

Herasymenko, N. P., Yurchenko, T. I., Chernovol, D. K. 2018. Pryrodna y antropohenna transformatsiia roslynnosti ta gruntovoho pokryvu na trypilskomu poselenni Ozheve-ostriv (Serednie Prydnister'ia). In: Relief i klimat: Materialy IIoi mizhnarodnoi konferentsii. Chernivtsi, s. 39-41.

Diachenko, A. V. 2010. Evstaticheskie kolebaniia Chernogo moria i dinamika razvitiia naseleniia kukuten-tripolskoi obshchnosti. Stratum plus, 2, s. 37-48.

Kochkin, I. T. 1987. Otchet o rabote ekspeditsii IvanoFrankovskogo gosudarstvennogo pedagogicheskogo instituta im. Stefanika po issledovaniiu tripolskogo poseleniia Beleluia 6 (ur. "Bavki») v $1987 \mathrm{~g}$. NA IA NAN Ukrainy, f. 64 1987/110.

Kruts, V. A., Ryzhov, S. N., Zbenovich, V. G., Shumova, V. A. 1981. Otchet o rabote taliankovskogo otriada Tripolskoi ekspeditsii za 1981 g. NA IA NAN Ukrainy, f. 64, 1981/11b.

Kruts, V. A., Ryzhov, S. N., Shumova, V. A. 1983. Otchet o rabote taliankouskogo otriada Tripolskoi ekspeditsii za $1983 \mathrm{~g}$. NA IA NAN Ukrainy, f. 64, 1983/3a.

Kruts, V. A., Ryzhov, S. N., Shumova, V. A., Salii, N. G. 1984. Otchet o rabote taliankouskogo otriada Tripolskoi ekspeditsii za $1984 \mathrm{~g}$. NA IA NAN Ukrainy, f. 64, 1984/38.

Kruts, V. A., Ryzhov, S. N., Klochko, V. I. 1985. Otchet o rabote taliankouskogo otriada Tripolskoi ekspeditsii za $1985 \mathrm{~g}$. NA IA NAN Ukrainy, f. 64, 1985/23e.

Kruts, V. A., Korvin-Piotrovskii, A. G., Ryzhov, S. N., Buzian, G. N., Ovchinnikov, E. V., Chernovol, D. K., Chabaniuk, V. V. 2005. Issledovaniia poselenii-gigantov tripolskoi kultury 2002-2004 gg. Kiev: Korvin-Press.

Kruts, V. A., Korvin-Piotrovskii, A. G., Menotti, F., Ryzhov, S. N., Chernovol, D. K., Chabaniuk, V. V. 2008. Tripolskoe poselenie-gigant Talianki. Issledovaniia $2008 \mathrm{~g}$. Kiev.
Kruts, V. A., Korvin-Piotrovskii, A. G., Chabaniuk, V. V., Shatilo, L. A. 2013. Tripolskoe poselenie-gigant Talianki. Issledovaniia $2012 \mathrm{~g}$. Kiev.

Makarevich, M. L. 1948. Otchet Sredne-Bugskoi ekspeditsii na poselenii Sabatinovka II. NA IA NAN Ukrainy, f. 64, 1948/34.

Makarevich, M. L. 1960. Ob ideologicheskikh predstavleniiakh u tripolskikh plemen. Zapiski Odesskogo arkheologicheskogo obshchestva, 1 (34), s. 290-301.

Morgan, L. 1934. Doma $i$ domashniaia zhizn amerikanskikh tuzemtsev. Leningrad: Institut narodov severov TsIK SSSR.

Ovchinnikov, E. V., Chernovol, D. K. 2001. Raskopki tripolskogo poseleniia Zelena Dibrova. Arkheolohichni vidkryttia $v$ Ukraini 1999-2000 rr., s. 177-179.

Ovchynnykov, E. V. 2014. Trypilska kultura Kanivskoho Podniprov'ia (etapy BII-CI). Kyiv: Oleh Filiuk.

Passek, T. S. 1949. Periodizatsiia tripolskikh poselenii. Materialy i issledovaniia po arkheologii SSSR, 10. Moskva; Leningrad: AN SSSR.

Passek, T. S. 1961. Rannezemledelcheskie (tripolskie) plemena Podnestrovia. Materialy i issledovaniia po arkheologii SSSR, 84. Moskva: AN SSSR.

Popova, T. A. 2003. Mnogosloinoe poselenie Polivanov Iar: $K$ evoliutsii tripolskoi kultury v Srednem Podnestrove. SanktPeterburg: MAE RAN.

Ryzhov, S. M., Shumova, V. O., Chernovol, D. K. 2005. Doslidzhennia trypilskoho poselennia Kolodyste II u $2004 \mathrm{r}$. Arkheolohichni doslidzhennia v Ukraini 2003-2004 rr., s. $274-276$

Sokhatskyi, M. P. 1992. Zvit pro robotu arkheolohichnoi ekspedytsii Borshchivskoho viddilu Ternopilskoho kraieznavchoho muzeiu u 1992 rotsi. NA IA NAN Ukrainy, f. 64, 1992/109.

Sokhatskyi, M. P. 1995. Zvit pro robotu arkheolohichnoi ekspedytsii Borshchivskoho viddilu Ternopilskoho kraieznavchoho muzeiu u 1992 rotsi. NA IA NAN Ukrainy, f. 64, 1995/40.

Tsvek, E. V. 1972. Otchet o raskopkakh tripolskogo poseleniia u s. Shkarovka Belotserkovskogo r-na Kievskoi oblasti v 1971-1972 g. NA IA NAN Ukrainy, f. 64, 1971-72/6.

Tsvek, E. V. 1976. Domostroitelstvo i planirovka tripolskikh poselenii (po materialam rasskopok v s. Shkarovka). In: Berezanskaia, S. S. Otroshchenko, V. V., Telegin, D. Ia. (ed.). Eneolit $i$ bronzouyi vek Ukrainy Issledovaniia $i$ materialy. Kiev: Naukova dumka, s. 46-69.

Tsvek, O. V. 1993. Relihiini uiavlennia naselennia Trypillia. Arkheolohiia, 3, s. 74-90.

Chernysh, E. K. 1962. Neolit i eneolit iuga evropeiskoi chasti SSSR. Materialy $i$ issledovaniia po arkheologii SSSR, 102, s. $5-85$

Chernovol, D. K., Ryzhov, S. M. 2005. Zvit Pishchanskoho zahonu Trypilskoi ekspedytsii za 2005 rik v s. Pishchana Talnivskoho raionu Cherkaskoi oblasti. NA IA NAN Ukrainy, f. $64,2005 / 135$.

Chernovol, D. K. 2008. Interer tripolskogo zhilishcha po materialam poseleniia Talianki. In: Korvin-Piotrovskii, A., Menotti, F. (ed.). Tripolskaia kultura v Ukraine. Poselenie-gigant Talianki. Kiev, s. 168-191.

Chernovol, D. K., Sokhatskyi, M. P. 2010. Inter'ier zhytel zalishchytskoi lokalnoi hrupy za materialamy poselennia Hlybochok Borshchivskoho raionu Ternopilskoi oblasti. Arkheolohiia i davnia istoriia Ukrainy, 2, s. 32-35.

Chernovol, D. K. 2012. Inter'ier budivel nebelivskoi lokalnoi hrupy trypilskoi kultury. Arkheolohiia, 1, s. 62-71.

Chernovol, D. 2013. Postroiki petrenskoi lokalnoi gruppy. Revista Archeologică, IX, 1, s. 72-87.

Chernovol, D. K. 2015. Varianty zhytlovykh sporud za elementamy inter'ieru. In: Na skhidnii mezhi Staroi Yevropy. Materialy mizhnarodnoi naukovoi konferentsii. Kirovohrad, s. 53.

Chernovol, D. 2016. Poselenie tripolskoi kultury Bernashevka I. Revista Archeologică, XII, 1-2, s. 61-80.

Chernovol, D. K. 2017. Doslidzhennia v s. Voloshkove. In: Arkheolohiia Bukovyny: zdobutky ta perspektyvy. Tezy dopovidei naukovoho seminaru. Chernivtsi: Tekhnodruk, s. 84-85.

Shmaglii, N. M., Videiko, M. Iu. 1985 Otchet o rabote Maidanetskogo otriada Tripolskoi ekspeditsii v 1985 godu. NA IA NAN Ukrainy, f. 64, 1985/23v. 
Anthony, D. 2007. The horse, the wheel and language. How Bronze Age riders from the Eurasian steppes shaped the modern world. Princepton: Princeton University.

Bicbaev, V. 2010. The Copper Age cemetery in Giurgiulesti. In: Anthony, D. (ed.). The lost world of Old Europe. Prin cepton: Princeton University, p. 212-224.

Chernovol, D. 2012. Houses of the Tomashovskaya local group. In: Menotti, F., Korvin-Piotrovskiy, A. G. (eds.). The Tripolye culture giant-settlements in Ukraine: formation, de velopment and decline. Oxford: Oxbow Books, p. 182-210.

Chernovol, D. 2014. The Tripolye BI Dwellings in the Middle Dniester Region. In: Cucuteni Culture within the European Neo-Eneolithic Context: International Colloquium Cucu teni - 130. Piatra-Neamt: Constantin Matasa, p. 108-109.

Harper, T. K., Diachenko, A., Rassamakin, Y. Y., Kennett, D. J. 2019. Ecological dimensions of population dynamics and subsistence in Neo-Eneolithic Eastern Europe. Journal of Anthropological Archaeology, 53, p. 92-101.

\section{K. Chernovol}

\section{VARIATIONS OF THE TRYPILLIA CULTURE HOUSES ACCORDING TO THE INTERIOR OF THE SECOND STOREY}

Oven is a permanent element of interior of the Trypillia culture house. An oven is always located to the right from the entrance to the residential room of the second storey. Other interior details, such as altar, podium etc, are not met in every single house. This paper aims to define variations of the Trypillia culture houses according to the presence or lack of elements of interior. Origin of variations is analyzed according to the chronology of sites. The analysis is focused only on the interior of the second storey.
Fifteen variations of Trypillia houses were defined as of today. Variations one to three are typical only for Early Trypillia. Those are different from the latter variations by the location of an oven. Variations four to six were formed during the Trypillia BI stage and lasted till Trypillia CII. Other variations characterize slight differences between certain periods of culture. Organization of interior did not change much since Trypillia BI. However Trypillia BI is characterized by its highest variation.

The high level of unification of the Trypillia culture dwellings was probably caused by the fact that the house construction was the collective activity. Different taboos, which did not let the deviation from commonly accepted rules, also should not be excluded. Certain individual elements could appear in the result of house construction by an individual or family. They could be also caused by the functioning of house and some rational reasons.

Change in the location of an oven during Trypillia BI could be explained by the climate change during this period of time, which was noted by the number of scholars, or incorporation of people from different cultural units into Trypillia populations.

Keywords: Trypillia culture, variations of houses, ploshchadka, interior.

Одержано 4.10.2020

ЧЕРНОВОЛ Дмитро Костянтинович, кандидат історичних наук, науковий співробітник, Інститут археології НАН України, Київ, Україна.

CHERNOVOL Dmytro K., PhD, Senior Researcher, Institute of Archaeology, National Academy of Sciences of Ukraine, Kyiv, Ukraine.

ORCID: 0000-0001-8208-0355, e-mail: ch_d_k@ukr.net. 